Bangladesh J. Sci. Ind. Res. 42(3), 335-340, 2007

\title{
On-farm Evaluation of Three Mustard Varieties Under Different Fertilizer Packages
}

\author{
N. C. Basak, ${ }^{\text {a J. C. Pandit }}{ }^{\text {b }}$ and M. M. H. Khurram ${ }^{c}$ \\ ${ }^{\mathrm{a} O n-F a r m ~ R e s e a r c h ~ D i v i s i o n ~ B a n g l a d e s h ~ A g r i c u l t u r a l ~ R e s e a r c h ~ I n s t i t u t e, ~ M y m e n s i n g h-2200, ~}$ \\ ${ }^{\mathrm{b}}$ Departmennt of Agricultural Extension, Farmgate, Khamarbari, Dhaka-1215, Bangladesh \\ and ${ }^{\mathrm{C}}$ Oilseed Research Centre, BARI, Joydebpur, Gazipur, Bangladesh.
}

\begin{abstract}
A field experiment was conducted on Non-Calcareous Dark Grey Floodplain Soil to find out the performance of three mustard varieties viz., i) BARI Sarisha-9, ii) BARI Sarisha-12 and iii) Tori-7 (Local) and three fertilizer doses as : $\mathrm{F}_{1}=120-34-64-32-1.5$ $\mathrm{kg} / \mathrm{ha}$ NPKSB (HYG), $\mathrm{F}_{2}=86-26-44-26-1.0 \mathrm{~kg} / \mathrm{ha}$ NPKSB (MYG) and $\mathrm{F}_{3}=54-60-$ $15 \mathrm{~kg} / \mathrm{ha}$ NPK. The variety BARI sarisha-9 produced the highest seed yield (892 $\mathrm{kg} / \mathrm{ha})$. The fertilizer level of HYG gave higher seed yield $(956 \mathrm{~kg} / \mathrm{ha})$. BARI Sharisha-9 gave higher gross return (Tk. 21882/ha) and gross margin (Tk.14936/ha) under HYG fertilizer level but higher BCR (3.54) was recorded under MYG fertilizer level due to less fertilization cost.
\end{abstract}

Key words : Mustard, Variety, Fertilizer, Yield, Economics.

\section{Introduction}

Mustard is an important oil seed crop in Bangladesh. It accounts about $72 \%$ of total oilseed production in the country. The area under rapeseed and mustard is 0.30 million hectares which is about $80 \%$ of the total oilseed area (Anon. 2003). But the area under mustard is declining due to late harvesting of high yielding T. aman rice and increased cultivation of boro rice. Last ten years have witnessed gradual decline in an area of 104 thousand hectare and production 68 thousand tons of mustard and rapeseed (Anon. 2006).
Though the production of edible oil is being decreased, but the demand is increasing day by day with the increasing population. The present domestic edible oilseed production is 267 thousand tons which meets only one third of national demand (Anon. 2006). The present per capita oil consumption is only 10 g/day as compared to the total need of 22 g/day (Anon. 2000). The shortage of edible oil in the country has become an acute problem. To fulfill this demand, Bangladesh has to import a large quantity of edible oil every 
year at the cost of huge amount of foreign exchange worth some Tk.11000 million (Anon. 2006).

Cultivation of low yielder local varieties with poor fertilizer management are the major causes for poor yield of mustard in the country (Alam and Rahman. 2006). High yield potential of a variety is the prerequisite for increasing the production of a crop. In the recent years, Bangladesh Agricultural Research Institute (BARI) has developed a number of high yielding varieties of mustard with yield potential up to $2.5 \mathrm{t} / \mathrm{ha}$. The present national average yield of mustard is only 0.79 t/ha (Anon. 2006). In the Old Brahmaputra Floodplain (AEZ-9), the major cropping patterns are Mustard-Boro-T.Aman rice under medium high land and MustardBoro rice under medium low land. In those patterns, the farmers are using local variety of mustard with very poor fertilizer management and harvest very poor yield of mustard. By introducing the high yielding varieties with better fertilizer management packages the yield of mustard can be increased manifold.

So, the experiment was under taken to find out a suitable variety of mustard with economic fertilizer dose for realizing higher mustard yield in Mymensingh area i.e., AgroEcological Zone 9 of Bangladesh.

\section{Materials and Methods}

The experiment was conducted on NonCalcareous Dark Grey Floodplain Soil at
Charkalibari, Mymensingh, Bangladesh during two consecutive rabi (winter) seasons of 2004-05 and 2005-06. The experimental field belongs to medium low land of Old Brahmaputra Flood plain (AEZ-9) with silty clay loam in texture. The $\mathrm{pH}$ of the soil was 5.8. The soil contained $0.10 \%$ total $\mathrm{N}, 0.18$ meq/100 g exchangeable $\mathrm{K}$, and 2.15, 14.28, 2.64 and 0.18 ppm available P, S, Zn and B, respectively. The design of the experiment was randomized complete block with three replications. The unit plot size was 5' $4 \mathrm{~m}$. The treatments of the experiment were three mustard varieties viz, $\mathrm{V}_{1}=$ BARI Sarisha-9, $\mathrm{V}_{2}=$ BARI Sarisha- 12 and $\mathrm{V}_{3}=$ Tori-7 (Local) and three fertilizer doses viz., $F_{1}=120-34-64-$ $32-1.5 \mathrm{~kg} / \mathrm{ha}$ NPKSB (High Yield Goal), $\mathrm{F}_{2}=$ 86-26-44-26-1.0 kg/ha NPKSB (Moderate Yield Goal) and $F_{3}=54-60-15 \mathrm{~kg} /$ ha NPK (Farmers' practice). The sources of NPKS and B were urea, triple super phosphate, muriate of potash, gypsum and boric acid, respectively. Full amount of PKS and B and one third of $\mathrm{N}$ were applied as basal. Rest amount of $\mathrm{N}$ (as urea) was top dressed in two equal splits at 25 and 45 DAS. The seeds were sown on 1stweek of November @ 9.0 $\mathrm{kg} / \mathrm{ha}$ following broadcast method. Intercultural operations were done as and when necessary. The variety Tori-7 was harvested on 3rd week of January and other varieties were harvested on 4th week of January in both the years. Data on yield and yield contributing characters were recorded and analyzed statistically. Mean differences were adjudged by LSD test. Two years average 
yield and only the fertilizer costs were considered for the economic analysis as outlined by (Reddy and Reddi. 1992).

\section{Results and Discussion}

\section{Effect of variety}

Observations on yield and yield components of mustard revealed that the varieties differed significantly in respect of plant height, number of siliqua/plant, 1000-seed weight and seed yield (Table I). The highest plant height was recorded for BARI Sarisha-9 $(79.0 \mathrm{~cm})$ which was identical with BARI Sarisha-12 $(78.9 \mathrm{~cm})$ and significantly higher than Tori-7 $(76.8 \mathrm{~cm})$. In respect of number of siliqua/plant, BARI Sarisha-9 (41.16) and BARI Sarisha-12 (41.11) showed better performance over Tori-7 (35.17). Maximum 1000 -seed weight was produced by the variety BARI Sarisha-9 (2.88 g) which was significantly followed by BARI Sarisha-12 (2.75 g) and Tori-7 (2.62 g). Among the three varieties under study, the highest seed yield was produced by the variety BARI Sarisha- 9 (892 kg/ha) which was significantly followed by BARI Sarisha-12 (817 kg/ha). The lowest seed yield was recorded for Tori-7 (758 $\mathrm{kg} / \mathrm{ha}$ ). The seed yield of BARI Sarisha-9 and BARI Sarisha-12 were $18 \%$ and $8 \%$ higher than the local variety Tori-7. Similar increased yield in BARI Sarisha-9 (former line M-27) and BARI Sarisha-12 (former line PT-303) over Tori-7 was also observed in the regional yield trial (Anon. 1994). From the results, it was revealed that higher number of siliqua/plant and higher 1000-seed weight contributed to higher seed yield of BARI Sarisha-9.

\section{Effect of fertilizer}

Plant characters and seed and stover yields varied significantly in response to different levels of fertilizer (Table I). The fertilizer level, High Yield Goal (HYG) showed superiority in respect of plant height $(83.2 \mathrm{~cm})$, number of siliqua/plant (44.91), number of seed/siliqua (13.09), seed yield (956 kg/ha) and stover yield (1814 kg/ha). Mondal et al. (1996) reported that the highest seed yield of mustard (1.40 t/ha) was obtained from a fertilizer level of 150-90-100-30-4-1 kg/ha of N, P2O5, K2O, S, Zn and B, respectively. Higher yield contributing characters and yields in high management were also observed by Ahmed et al. (1999). The plant height $(81.2 \mathrm{~cm})$, number of seed/siliqua (12.50), seed yield (869 kg/ha) and stover yield (1678 kg/ha) were recorded for Moderate Yield Goal (MYG) level which was significantly lower than those of HYG level. However, number of siliqua/plant (43.06) and 1000-seed weight (2.86 g) in MYG level was identical with HYG level. The lowest plant height $(70.3 \mathrm{~cm})$, number of siliqua/plant (29.47), number of seed/siliqua (11.23), seed yield (642 kg/ha) and stover yield (1314 kg/ha) were recorded for farmers' 
Table I. Effect of variety, fertilizer and interaction effect on the growth, yield and yield components of mustard (Two years pooled)

\begin{tabular}{|c|c|c|c|c|c|c|c|}
\hline Treatment & $\begin{array}{c}\text { No. of } \\
\text { Plant } / \mathrm{m}^{2}\end{array}$ & $\begin{array}{c}\text { Plant } \\
\text { height }(\mathrm{cm})\end{array}$ & $\begin{array}{l}\text { No. of sili- } \\
\text { qua / plant }\end{array}$ & $\begin{array}{l}\text { No. of seed } \\
\text { / siliqua }\end{array}$ & $\begin{array}{l}\text { 1000-seed } \\
\text { weight (g) }\end{array}$ & $\begin{array}{c}\text { Seed yield } \\
\text { (kg / ha) }\end{array}$ & $\begin{array}{c}\text { Stover yield } \\
(\mathrm{kg} / \mathrm{ha})\end{array}$ \\
\hline & & & & & & & \\
\hline $\mathrm{V}_{1}$ & 114 & 79.0a & $41.16 a$ & 12.41 & $2.88 a$ & $892 a$ & 1617 \\
\hline $\mathrm{V}_{2}$ & 112 & 78.9a & $41.11 \mathrm{a}$ & 12.24 & $2.75 b$ & $817 \mathrm{~b}$ & 1603 \\
\hline $\mathrm{V}_{3}$ & 109 & $76.8 \mathrm{~b}$ & $35.17 \mathrm{~b}$ & 12.18 & $2.62 \mathrm{c}$ & $758 c$ & 1586 \\
\hline $\begin{array}{l}\text { Level of } \\
\text { Significance }\end{array}$ & NS & 0.01 & 0.01 & NS & 0.01 & 0.01 & NS \\
\hline $\mathrm{S}_{\mathrm{x}}$ & 1.42 & 0.45 & 0.72 & 0.10 & 0.02 & 12.34 & 33.28 \\
\hline$\overline{F_{1}}$ & 114 & $83.2 \mathrm{a}$ & $44.91 \mathrm{a}$ & 13.09a & $2.88 a$ & 956a & $1814 a$ \\
\hline $\mathrm{F}_{2}$ & 113 & $81.2 \mathrm{~b}$ & 43.06a & $12.50 \mathrm{~b}$ & $2.86 \mathrm{a}$ & $869 b$ & $1678 b$ \\
\hline $\mathrm{F}_{3}$ & 108 & 70.3c & $29.47 b$ & $11.23 \mathrm{c}$ & $2.51 \mathrm{~b}$ & 642c & $1314 c$ \\
\hline $\begin{array}{l}\text { Level of } \\
\text { Significance }\end{array}$ & NS & 0.01 & 0.01 & 0.01 & 0.01 & 0.01 & 0.01 \\
\hline $\mathrm{S}_{\mathrm{x}}$ & 1.42 & 0.45 & 0.72 & 0.10 & 0.02 & 12.34 & 33.28 \\
\hline$\overline{V_{1} F_{1}}$ & 119 & $85.1 \mathrm{a}$ & 47.20 & 12.92 & 2.90 & 1042 & 1875 \\
\hline $\mathrm{V}_{1} \mathrm{~F}_{2}$ & 112 & 81.0bc & 44.83 & 12.40 & 2.87 & 942 & 1717 \\
\hline $\mathrm{V}_{1} \mathrm{~F}_{3}$ & 113 & 70.7d & 31.30 & 11.40 & 2.57 & 692 & 1258 \\
\hline $\mathrm{V}_{2} \mathrm{~F}_{1}$ & 113 & $80.2 \mathrm{c}$ & 47.28 & 13.37 & 2.87 & 958 & 1783 \\
\hline $\mathrm{V}_{2} \mathrm{~F}_{2}$ & 112 & 78.9c & 44.27 & 12.68 & 2.85 & 850 & 1642 \\
\hline $\mathrm{V}_{2} \mathrm{~F}_{3}$ & 110 & $71.5 \mathrm{~d}$ & 31.92 & 11.18 & 2.53 & 642 & 1383 \\
\hline $\mathrm{V}_{3} \mathrm{~F}_{1}$ & 113 & $84.4 \mathrm{a}$ & 40.25 & 13.00 & 2.87 & 867 & 1783 \\
\hline $\mathrm{V}_{3} \mathrm{~F}_{2}$ & 111 & 83.7ab & 40.08 & 12.42 & 2.87 & 817 & 1675 \\
\hline $\mathrm{V}_{3} \mathrm{~F}_{3}$ & 104 & $68.7 d$ & 25.18 & 11.12 & 2.42 & 592 & 1300 \\
\hline $\begin{array}{l}\text { Level of } \\
\text { Significance }\end{array}$ & NS & 0.01 & NS & NS & NS & NS & NS \\
\hline $\mathrm{S}_{\mathrm{x}}$ & 2.47 & 0.78 & 1.25 & 0.18 & 0.03 & 21.38 & 57.65 \\
\hline CV (\%) & 5.42 & 2.46 & 7.80 & 3.56 & 2.57 & 6.37 & 8.82 \\
\hline
\end{tabular}

NS: not significant 
practice. The highest number of siliqua/plant, seed/siliqua and maximum 1000-seed weight resulted in the highest seed yield for the HYG fertilizer level.

\section{Interaction effect between variety and fertilizer}

Table I also shows that interaction effect of variety and fertilizer level was not significant except plant height. The tallest plant (85.1 $\mathrm{cm})$ was produced by the variety BARI Sarisha-9 under HYG fertilizer level and the shortest $(68.7 \mathrm{~cm})$ for Tori-7 under farmer's practice. However, all the varieties with HYG fertilizer level gave higher seed yield. The varieties BARI Sarisha-9, BARI Sarisha-12 and Tori-7 gave higher seed yield of $1042 \mathrm{~kg} / \mathrm{ha}, 958 \mathrm{~kg} / \mathrm{ha}$ and $867 \mathrm{~kg} / \mathrm{ha}$, respectively with HYG fertilizer level. Similar trend was followed in case of stover yield. Mamun (2005) reported the highest plant height $(90.83 \mathrm{~cm})$, number of siliqua/plant (79.25), number of seeds/siliqua (31.66), 1000 seed weight (3.86 g), seed yield (1.62 t/ha) and straw yield(3.22 t/ha) in the variety BINA Sarisha-5.

\section{Economic performance}

Higher gross return (Tk.21882/ha) and gross margin (Tk.14936/ha) were obtained from BARI Sarisha-9 with HYG fertilizer level. But benefit cost ratio (BCR) was the highest (3.54) in BARI Sarisha-9 with MYG fertilizer level. It might be due to lower variable cost in MYG. MYG fertilizer level also gave considerable BCR (3.20) in BARI Sarisha12. Farmers fertilizer dose showed lower yield as well as benefit cost ratio with all the varieties under study. Over all BARI Sarisha9 gave higher BCR in all fertilizer levels as compared to other varieties (Table II).

Table II. Economic analysis of different fertilizer dose on three mustard varieties (average of two years)

\begin{tabular}{l|c|c|c|c}
\hline Treatment & $\begin{array}{c}\text { Gross return } \\
(\mathrm{Tk} / \mathrm{ha})\end{array}$ & $\begin{array}{c}\text { *Variable cost } \\
(\mathrm{Tk} / \mathrm{ha})\end{array}$ & $\begin{array}{c}\text { Gross margin } \\
(\mathrm{Tk} / \mathrm{ha})\end{array}$ & $\begin{array}{c}\text { Benefit cost } \\
\text { ratio (BCR) }\end{array}$ \\
\hline $\mathrm{V}_{1} \mathrm{~F}_{1}$ & 21882 & 6946 & 14936 & 3.15 \\
$\mathrm{~V}_{1} \mathrm{~F}_{2}$ & 19782 & 5582 & 14200 & 3.54 \\
$\mathrm{~V}_{1} \mathrm{~F}_{3}$ & 14532 & 5309 & 9223 & 2.74 \\
$\mathrm{~V}_{2} \mathrm{~F}_{1}$ & 20118 & 6946 & 13172 & 2.90 \\
$\mathrm{~V}_{2} \mathrm{~F}_{2}$ & 17850 & 5582 & 12268 & 3.20 \\
$\mathrm{~V}_{2} \mathrm{~F}_{3}$ & 13482 & 5309 & 8173 & 2.54 \\
$\mathrm{~V}_{3} \mathrm{~F}_{1}$ & 18207 & 6946 & 11261 & 2.62 \\
$\mathrm{~V}_{3} \mathrm{~F}_{2}$ & 17157 & 5582 & 11575 & 3.07 \\
$\mathrm{~V}_{3} \mathrm{~F}_{3}$ & 12432 & 5309 & 7123 & 2.34 \\
\hline
\end{tabular}

*Variable cost includes only the fertilizer costs. 


\section{Conclusion}

The variety BARI Sarisha-9 with High Yield Goal fertilizer level may be recommended for the resource rich farmers of Old Brahmaputra Floodplain (AEZ-9) for higher lyield and economic return. The variety BARI Sarisha-9 with Moderate Yield Goal fertilizer level may also be recommended for the resource poor farmers for reasonable good yield and economic return.

\section{Reference}

Ahmed, F. Karim, M.R. and Jahan, M.A. (1999) Effect of different management practices on the productivity and profitability of mustard under late sown condition, Bangladesh $J$. Agril. Res. 24(3) : 425-430.

Alam, M.M. and Rahman, M.M. ( 2006) Effect of row spacing on seed yield of five varieties of Rapeseed, Bangladesh J. Crop Sci. 17(1) : 163-168.

Anonymous. (2006) Bangladesh Bureau of Statistics. Monthly Statistical Bulletin of Bangladesh. January, Statistics Div., Ministry of Planning, Govt. People's Repub. Bangladesh. 54.
Anonymous. (2003) Bangladesh Bureau of Statistics. Statistical Yearbook of Bangladesh, Statistics Div., Ministry of Planning, Govt. People's Repub. Bangladesh. 101-125.

Anonymous. (2000) Tel Fasaler Utpadan Prajukti (In Bangla), Oil Seed Res. Centre, Bangladesh Agril. Res. Inst., Joydebpur, Gazipur. 1-102.

Anonymous. (1994) Annual Report (1993-94), Bangladesh Agricultural Research Institute, Joydebpur, Gazipur. 251-253.

Mamun, F.A. (2005) Effect of different sources of nitrogenous fertilizers on the growth and yield of mustard mutant varieties. MS Thesis, Dept. of Agron., Bangladesh Agril. Univ., Mymensingh. 55-58.

Mondal, M.R.I. Fattah, Q.A. Chaudhury, A.J.M.H Podder, and P. Alam, M.S. (1996) Effect of fertilizers on yield and economic return of mustard. Dhaka Univ. J. Biol. Sci. 5(2) : 173-177

Reddy, T.Y. and Reddi, G.H.S. (1992). Principles of Agronomy. Kalyani Publishers. New Delhi-110 002, India. 423.

Received : February 25, 2001;

Accepted : July 04, 2007 